\title{
The effect of urbanization on soil properties and soil organic carbon accumulation in topsoil of Pruszków - a medium-sized city in the Warsaw Metropolitan Area, Poland
}

\begin{abstract}
The objective of the study was to determine properties of soils located within a city, and to assess the effect of anthropopressure on the accumulation of carbon and nitrogen in soils of Pruszków - a medium sized town in central Poland. Surface soil layers $(0-20 \mathrm{~cm})$ were collected at 36 sites. A total of 12 samples from lawns, 11 from allotment gardens, 9 from fields and 4 from fallow lands were subject to analysis. Lawns and allotment gardens were treated as central zone I - under strong pressure of anthropogenic factors, fields and fallow lands were treated as zone II - with potentially low level of anthropogenic influence. The statistical analysis showed significantly higher $\left(\mathrm{p}=0.008\right.$ ) amount of organic carbon (Corg) in lawns (mean $\left.20.5 \mathrm{~g} \cdot \mathrm{kg}^{-1}\right)$ and allotment gardens $\left(21.7 \mathrm{~g} \cdot \mathrm{kg}^{-1}\right)$ - zone I, than on fallow lands $\left(10.4 \mathrm{~g} \cdot \mathrm{kg}^{-1}\right)$ and fields $\left(1.27 \mathrm{~g} \cdot \mathrm{kg}^{-1}\right)$ - zone II. The surface layer of soil from allotment gardens also contained significantly higher amount of total nitrogen (mean content $1.1 \mathrm{~g} \cdot \mathrm{kg}^{-1}$ ) than others. The amounts of Corg not depending on the soil texture and very high $\mathrm{C} / \mathrm{N}$ ratio, suggests the anthropogenic origin of the carbon. The $\mathrm{C} / \mathrm{N}$ ratio was the highest in the soils of lawns (mean value 26.2) and significantly differed $(\mathrm{p}=0.04)$ from $\mathrm{C} / \mathrm{N}$ ratios in soils of fields and allotment gardens. This suggests low intensity of humus transformation. Other chemical characteristics as hydrolytic acidity (Ha), cation exchange capacity (CEC), exchangeable base cations (EBC) and EBC share in CEC were also higher in central part of Pruszków town (zone I), indicating the effect of urbanization on soil properties.
\end{abstract}

Key words: urban soils, land use, carbon accumulation, nitrogen, soil properties

\section{INTRODUCTION}

The urban development is observed globally (Vegter 2007) although urban soils are still one of the least recognized. With the development of cities they have been becoming more important but remain poorly characterized (Norra and Stüben 2003). Urbanization affects the natural environment. In Poland, urban areas increased in years 2004-2009 from 4.65 to $4.90 \%$. The largest increase was observed in the case of the housing land and land transportation (Ministry of Regional Development 2010).

City environment is affected by man to a greater extent than others. It has specific conditions, caused by physical, mechanical or chemical human impacts. Urban soils are under disturbances leading to acidification or alkalisation, salinity, heavy metals accumulation and other. They differ from natural soils. Forest or agricultural soils within cities also show differences in comparison with the soils of the same use, but localized far from the city (Pouyat et al. 2002; Edmondson et al. 2012). Studies in large cities of Europe, the U.S. and China suggest that urban soils are enriched in organic carbon. Sometimes the enrichment concerns residential areas
(Pouyat et al. 2002). In other cities more carbon is accumulated in green areas, where naturally more soil organic matter returns to the soil (Liu et al. 2013). Soils in cities could be enriched in carbon compounds resulting from air pollution - combustion of fuels and other materials containing high amounts of carbon, as well as from car tire abrasion (Beyer et al. 1995; Chuai et al. 2012; Edmondson et al. 2012; Liu et al. 2013). In Poland, $\mathrm{CO}_{2}$ emissions by means of transport in 2005 was 32734 thousand tons, and 7128 thousand tons more in 2008 (GUS 2011). Parallel to the development of transport infrastructure, continues increases the number of cars and other means of transport and fuel consumption is still observed. A study by Bielińska et al. (2009) concerning change in organic carbon content in the area of allotment gardens revealed that the soils located in the direct vicinity of the activity of anthropogenic factors are richer in total carbon than soils in suburban areas of cities. Apart from intensive fertilisation of the allotment gardens with compost, manure, and peat, Bielińska et al. (2009) also point to dry and wet precipitation as the factor modifying organic carbon abundance. Organic carbon content is one of the most important soil properties. As the 
humus is one of the main components in soil, the quantity of this element is the indicator of environmental quality.

The knowledge about functioning of urban soils and their characteristics is necessary. This is particularly important in the context of changing climate and soil possibility to bind the carbon dioxide (Brown et al. 2012). Urban environments, as well as the soil in the cities so far have not been taken into account in estimates of carbon balance in the environment.

The objective of the study was to assess the effect of anthropopressure on the carbon and nitrogen accumulation in soils of medium sized town in the Warsaw Metropolitan Area, which underwent dynamic development in recent years.

\section{STUDY AREA}

The study was conducted in central Poland, in the town of Pruszków $\left(52.220^{\circ} \mathrm{N}, 20.819^{\circ} \mathrm{E}\right)$, located in the vicinity of Warsaw - the capital city of Poland. The area of the town is currently 1.915 ha, with a population of 54904 . During the last 20 years, the town underwent dynamic development, particularly related to the political transformations in Poland, resulting in the evolution of industry and transport, and intensive growth of residential construction. Three important regional roads intersect in the town's centre, generating high levels of traffic.

The study covered areas located in the central zone I - under strong pressure of anthropogenic factors (busy transportation routes), and the zone II - with a potentially low level of anthropogenic influence. In zone I, soil samples were taken from lawn areas (including boundaries of parks), and from allotment gardens. Zone II covered cultivated fields and fallow lands, located within the city boundaries.

The study area is flat. The present landforms developed during the middle-Polish (Riss) glaciation period. Silts and sands are dominant.

\section{MATERIALS AND METHODS}

Thirty six soil samples were collected in 2005 by means of a stainless steel tube from a depth of $0-20 \mathrm{~cm}$. A total of 9 samples from fields, 12 from lawns, 11 from allotment gardens, and 4 from fallow lands were subject to analysis. Each sample was a mixture of over a dozen subsamples. The samples were dried at room temperature, gently ground to crush aggregates, and then sieved through a $1 \mathrm{~mm}$ sieve. For the purposes of carbon and nitrogen analyses, some of the soil was ground again manually in flinty mortar, in order to obtain a grain diameter $<0.25 \mathrm{~mm}$.
Analyses were conducted using methods common in soil science (Van Reeuwijk 2002):

- organic carbon (Corg) was measured by catalytic burning to $\mathrm{CO}_{2}$ in $900^{\circ} \mathrm{C}$ in a Shimadzu 5000A TOC analyzer,

- total nitrogen $(\mathrm{Nt})$ was determined with the application of the modified Kjeldahl method in a Kjeltec-Tecator analyzer,

- the $\mathrm{pH}$ was determined following the potentiometric method attaining soil weight to $1 \mathrm{M} \mathrm{KCl}$ at $1: 2.5$,

- hydrolytic acidity (Ha) by extraction with ammonium acetate at $\mathrm{pH}=8.2$,

- total exchangeable base cations (EBC) by extraction with $0.1 \mathrm{M} \mathrm{HCl}$,

- cations exchange capacity (CEC) of the soil was calculated as sum of $\mathrm{Ha}$ and $\mathrm{EBC}$,

- samples with a high $\mathrm{pH}$ value $(>6.5)$ were treated with $10 \% \mathrm{HCl}$ in order to determine the presence of carbonates using Scheibler method,

- the particle-size distributions of soils were analyzed with Cassagrande' procedure with Prószyński modification. The names of texture classes were given according to Polish Soil Science Society classification (Komisja V Genezy, Klasyfikacji i Kartografii Gleb PTG 1989).

Multiple-Sample Comparison tests were conducted with the application of the STATGRAPHICS Plus 4.1 software. After verification of the occurrence of any significant differences between the mean values by means of the F-test in the ANOVA table, Multiple Range Tests were applied in order to determine which mean values are significantly different from the remaining ones. Additionally, simple regression analysis was used to describe the relationship between soils textures and some chemical properties $(\mathrm{pH}, \mathrm{Ha}, \mathrm{CEC}$, Corg) and between organic carbon content and soil acidity and CEC.

\section{RESULTS}

\section{Basic soil properties}

The chemical properties of the soils of Pruszków varied between the spot studied. Differences were recorded, both in soils under differing land use, and within areas subject to one type of land use. No occurrence of carbonates was recorded at any of the analysed sites.

The highest variability of features was observed in the soils of lawns. They showed both the lowest and the highest value of $\mathrm{pH}$ in $\mathrm{KCl}$ among all the soils analysed. The values varied from 3.7 to 7.6 (Table 1). This suggests the presence of strongly acidic, 
TABLE 1 . Some chemical properties of humus horizons $(0-20 \mathrm{~cm})$ from lawns $(\mathrm{n}=12)$

\begin{tabular}{llllclccc}
\hline Value & $\begin{array}{l}\mathrm{pH} \\
(\mathrm{KCl})\end{array}$ & $\begin{array}{l}\mathrm{Nt} \\
\left(\mathrm{g} \cdot \mathrm{kg}^{-1}\right)\end{array}$ & $\begin{array}{l}\text { Corg } \\
\left(\mathrm{g} \cdot \mathrm{kg}^{-1}\right)\end{array}$ & $\mathrm{C} / \mathrm{N}$ & $\begin{array}{l}\mathrm{Ha} \\
\left(\mathrm{cmol} \cdot \mathrm{kg}^{-1}\right)\end{array}$ & $\begin{array}{l}\mathrm{EBC} \\
\left(\mathrm{cmol} \cdot \mathrm{kg}^{-1}\right)\end{array}$ & $\begin{array}{l}\mathrm{CEC} \\
\left(\mathrm{cmol}^{\left.-\mathrm{kg}^{-1}\right)}\right.\end{array}$ & $\begin{array}{l}\mathrm{EBC} \text { in CEC } \\
(\%)\end{array}$ \\
\hline The lowest & 3.7 & 0.5 & 11.1 & 7.6 & 1.0 & 2.3 & 9.8 & 23.6 \\
\hline The highest & 7.6 & 1.5 & 35.2 & 35.6 & 7.5 & 33.6 & 36.5 & 96.3 \\
\hline Standard deviation & 1.1 & 0.3 & 6.6 & 7.3 & 2.0 & 8.2 & 8.7 & 22.0 \\
\hline Mean & 6.2 & 0.8 & 20.5 & 26.2 & 2.7 & 14.5 & 17.2 & 79.1 \\
\hline
\end{tabular}

TABLE 2. Some chemical properties of humus horizons $(0-20 \mathrm{~cm})$ from allotment gardens $(\mathrm{n}=11)$

\begin{tabular}{lllllllll}
\hline Value & $\begin{array}{l}\mathrm{pH} \\
(\mathrm{KCl})\end{array}$ & $\begin{array}{l}\mathrm{Nt} \\
\left(\mathrm{g} \cdot \mathrm{kg}^{-1}\right)\end{array}$ & $\begin{array}{l}\mathrm{Corg} \\
\left(\mathrm{g} \cdot \mathrm{kg}^{-1}\right)\end{array}$ & $\mathrm{C} / \mathrm{N}$ & $\begin{array}{l}\mathrm{Ha} \\
\left(\mathrm{cmol} \cdot \mathrm{kg}^{-1}\right)\end{array}$ & $\begin{array}{l}\mathrm{EBC} \\
\left(\mathrm{cmol} \cdot \mathrm{kg}^{-1}\right)\end{array}$ & $\begin{array}{l}\mathrm{CEC} \\
\left(\mathrm{cmol}^{\left.-\mathrm{kg}^{-1}\right)}\right.\end{array}$ & $\begin{array}{l}\text { EBC in CEC } \\
(\%)\end{array}$ \\
\hline The lowest & 5.9 & 0.6 & 12.5 & 17.3 & 0.8 & 13.6 & 14.6 & 84.9 \\
\hline The highest & 7.3 & 1.9 & 36.9 & 21.5 & 2.9 & 46.3 & 47.3 & 98.1 \\
\hline Standard deviation & 0.5 & 0.4 & 7.3 & 1.2 & 0.8 & 11.7 & 11.7 & 3.9 \\
\hline Mean & 6.9 & 1.1 & 21.7 & 19.6 & 1.4 & 30.7 & 32.1 & 94.8 \\
\hline
\end{tabular}

acidic, slightly acidic, neutral, and even alkaline soils. At the site with the lowest $\mathrm{pH}$ value, also the highest hydrolytic acidity among the studied soils was recorded $\left(7.5 \mathrm{cmol} \cdot \mathrm{kg}^{-1}\right)$. Mean hydrolytic acidity in soils of lawns amounted to $2.7 \mathrm{cmol} \cdot \mathrm{kg}^{-1}$. High hydrolytic acidity was related to high sorption capacity of all of the soils of lawns $\left(9.8-36.5 \mathrm{cmol} \cdot \mathrm{kg}^{-1}\right)$. Saturation of the sorption complex with alkaline cations at some of sites exceeded $90 \%$, but the mean values in soils of lawns were lower than $80 \%$ (Table 1). The texture in soils of this way of use was not variable as in soils of other use. The prevailing type was sand, with very low content of colloidal parts (Table 5).

Soils under the remaining types of land use also showed variability of basic chemical properties, but not as high as in the lawn soils discussed.

Soils of the allotment gardens mainly showed neutral reaction (Table 2). They were distinguished by a very high sorption capacity reaching 32.1 $\mathrm{cmol} \cdot \mathrm{kg}^{-1}$ on the average (the highest between other way of use), and high contribution of alkaline cations in the sorption complex, amounting to $94.8 \%$ on the average. In most cases, soils contained big amount of silt, in others texture types were sands.

Soils of fields were distinguished by reaction ranging from acidic to neutral, with the prevalence of the former (Table 3 ). The sorption capacity at most sites was lower than $9 \mathrm{cmol} \cdot \mathrm{kg}^{-1}$. It reached very high values of 23.0 and $26.6 \mathrm{cmol} \cdot \mathrm{kg}^{-1}$ in only two cases. At those sites, also the highest saturation of the sorption complex with alkaline cations was recorded, amounting to $96.6 \%$. In the remaining cases, it was substantially lower (Table 3). The particle size distribution in field soils was very similar to that of allotment gardens.

In terms of chemical soil properties, fallow land were the most similar to cultivated fields (Table 3

TABLE 3. Some chemical properties of humus horizons $(0-20 \mathrm{~cm})$ from fields $(\mathrm{n}=9)$

\begin{tabular}{llllccccc}
\hline Value & $\begin{array}{l}\mathrm{pH} \\
(\mathrm{KCl})\end{array}$ & $\begin{array}{l}\mathrm{Nt} \\
\left(\mathrm{g} \cdot \mathrm{kg}^{-1}\right)\end{array}$ & $\begin{array}{l}\text { Corg } \\
\left(\mathrm{g} \cdot \mathrm{kg}^{-1}\right)\end{array}$ & $\mathrm{C} / \mathrm{N}$ & $\begin{array}{l}\mathrm{Ha} \\
\left(\mathrm{cmol} \cdot \mathrm{kg}^{-1}\right)\end{array}$ & $\begin{array}{l}\mathrm{EBC} \\
\left(\mathrm{cmol} \cdot \mathrm{kg}^{-1}\right)\end{array}$ & $\begin{array}{l}\text { CEC } \\
\left(\mathrm{cmol}^{\left.-1 \mathrm{~kg}^{-1}\right)}\right.\end{array}$ & $\begin{array}{l}\text { EBC in CEC } \\
(\%)\end{array}$ \\
\hline The lowest & 4.5 & 0.4 & 6.7 & 15.8 & 0.8 & 3.1 & 5.4 & 47.6 \\
\hline The highest & 7.2 & 1.4 & 29.2 & 35.0 & 3.9 & 24.7 & 26.6 & 96.6 \\
\hline Standard deviation & 0.9 & 0.3 & 8.3 & 6.4 & 0.8 & 7.9 & 7.9 & 16.4 \\
\hline Mean & 5.5 & 0.6 & 12.7 & 21.2 & 2.1 & 9.0 & 11.1 & 73.0 \\
\hline
\end{tabular}

TABLE 4. Some chemical properties of humus horizons $(0-20 \mathrm{~cm})$ from fallow lands $(\mathrm{n}=4)$

\begin{tabular}{llllclccc}
\hline Value & $\begin{array}{l}\mathrm{pH} \\
(\mathrm{KCl})\end{array}$ & $\begin{array}{l}\mathrm{Nt} \\
\left(\mathrm{g} \cdot \mathrm{kg}^{-1}\right)\end{array}$ & $\begin{array}{l}\text { Corg } \\
\left(\mathrm{g} \cdot \mathrm{kg}^{-1}\right)\end{array}$ & $\mathrm{C} / \mathrm{N}$ & $\begin{array}{l}\mathrm{Ha} \\
\left(\mathrm{cmol} \cdot \mathrm{kg}^{-1}\right)\end{array}$ & $\begin{array}{l}\mathrm{EBC} \\
\left(\mathrm{cmol} \cdot \mathrm{kg}^{-1}\right)\end{array}$ & $\begin{array}{l}\mathrm{CEC} \\
\left(\mathrm{cmol}^{\left.-\mathrm{kg}^{-1}\right)}\right.\end{array}$ & $\begin{array}{l}\mathrm{EBC} \text { in CEC } \\
(\%)\end{array}$ \\
\hline The lowest & 4.6 & 0.3 & 7.9 & 20.0 & 0.6 & 3.5 & 6.5 & 53.2 \\
\hline The highest & 7.3 & 0.7 & 13.3 & 24.2 & 3.0 & 11.7 & 12.3 & 94.8 \\
\hline Standard deviation & 1.2 & 0.2 & 2.3 & 1.9 & 1.0 & 2.4 & 3.0 & 18.2 \\
\hline Mean & 5.9 & 0.5 & 10.4 & 22.0 & 1.7 & 7.7 & 9.4 & 78.3 \\
\hline
\end{tabular}


and 4). The reaction of soil in this land use category varied from acidic to alkaline, but due to a low number of samples, the assessment of these soils was difficult. The sorption capacity in this group of soils was quite high, amounting to $6.5-12.3 \mathrm{cmol} \cdot \mathrm{kg}^{-1}$, with a slight contribution of alkaline cations $(78.3 \%$ on average). Sands were textures of soils in this type of use.

Although soils of zone I had slightly higher hydrolytic acidity than soils of zone II, the amount of exchangeable base cations (EBC) in soils of zone I was twice higher the amount in soils of zone II. This caused a greater cations exchange capacity (CEC) and larger share of EBC in CEC in upper soils layers of lawns and allotment gardens (Fig. 1).

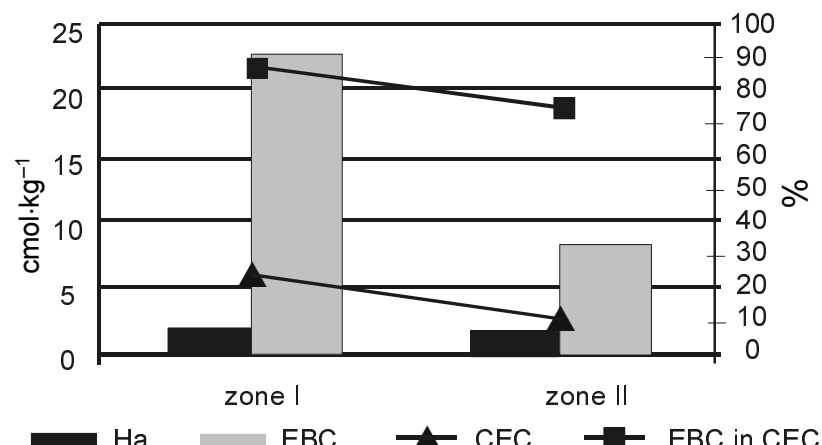

(Ha- Hydrolytic acidity, EBC - Exhangeable Base Cations, CEC - Cations Exchange Capacity)

FIGURE 1. Mean values of Hh, EBC, CEC and share EBC in CEC in soils of zone I and II

\section{Carbon, nitrogen content and $\mathrm{C} / \mathrm{N}$ ratio}

The highest amounts of organic carbon were recorded in the soils of zone I (Fig. 2): soils of allotment gardens and lawns. Its mean content in the soil of allotment gardens amounted to $21.7 \mathrm{~g} \cdot \mathrm{kg}^{-1}$ (Table 2 ) and in the soil of lawns to $20.5 \mathrm{~g} \cdot \mathrm{kg}^{-1}$ (Table 1), whereas the values in particular places were largely varied. The soils of allotment gardens also had the highest content of total nitrogen, with a mean value of $1.1 \mathrm{~g} \cdot \mathrm{kg}^{-1}$. The garden owners sometimes brought

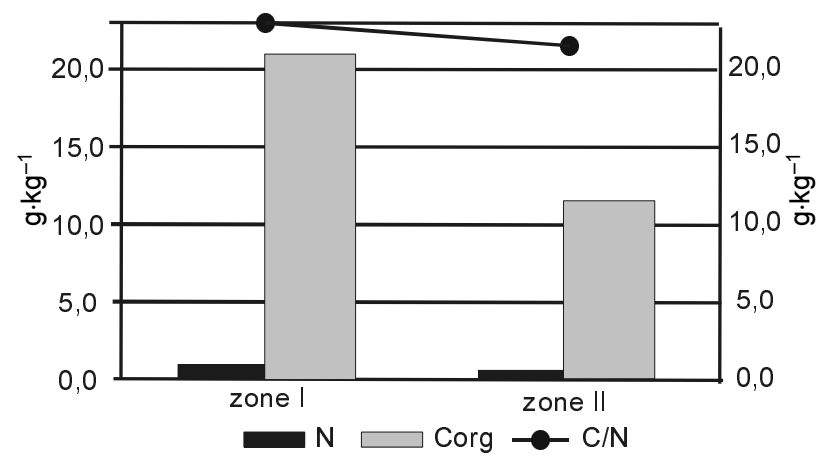

FIGURE 2. Mean values of $\mathrm{Nt}$, Corg and $\mathrm{C} / \mathrm{N}$ ratio in soils of zone I and II soils from outside. The new material may have. completely different properties than soil naturally occurring there.

In spite of the high variability of chemical properties of the soils of lawns, total nitrogen content was a quite homogenous characteristic for all of the sites (Table 1). The mean value of $0.8 \mathrm{~g} \cdot \mathrm{kg}^{-1}$ was also the most frequently recorded content in these soils. As a result, at high and quite varied organic carbon content, the $\mathrm{C} / \mathrm{N}$ ratio was variable. Both the highest and the lowest of the determined values occurred in the soils of lawns. The above data suggest that the soils were very diverse, with varied dynamics of organic matter transformations.

The soils of zone II contain considerably less carbon and nitrogen (Fig. 2). In cultivated fields, a mean carbon content of $12.7 \mathrm{~g} \cdot \mathrm{kg}^{-1}$ was determined. The mean nitrogen content reaches $0.6 \mathrm{~g} \cdot \mathrm{kg}^{-1}$. The $\mathrm{C} / \mathrm{N}$ ratio was higher than in allotment gardens but lower than in lawns.

Fallow lands were distinguished by the lowest mean contents of organic carbon $\left(10.4 \mathrm{~g} \cdot \mathrm{kg}^{-1}\right)$ and total nitrogen $\left(0.5 \mathrm{~g} \cdot \mathrm{kg}^{-1}\right)$, and high $\mathrm{C} / \mathrm{N}$ ratio (Table 4).

\section{DISCUSSION}

Pedological research has so far particularly concerned the properties and processes occurring in natural soils, or soils under various types of land management - in cultivated fields, forests, or meadows. Attention paid to urban soils mainly regarded their pollution. They are usually regarded as degraded. It is worthwhile, however, looking at urban soils from a different perspective. Soils in cities are used in a highly varied manner. They include cultivated fields, forests, parks, allotment gardens, and of course soils under hardened surfaces, such as asphalt and pavements. Varied land management must result in varied effect on soil properties.

In the scope of this study, a comparison was performed between the properties of soils within an intensively developing town in the vicinity of the capital city. The study revealed a varied character of the soils studied, both within a single type of land use, and between its different types. Varied properties of similarly used soils are highly determined by natural factors. Land use should be treated as an anthropogenic factor. In cities, physical transformation of soils, or even importing new material on the surface, is very common. This study also covers such a phenomenon. The surface layer of soils of the allotment gardens was brought there from other places and additionally usually was improved with organic amendments. This probably affected the soil texture, which in that area 
TABLE 5. Particle-size distribution of studied soils

\begin{tabular}{|c|c|c|c|c|c|c|c|c|c|}
\hline \multirow{2}{*}{$\begin{array}{l}\text { Sample } \\
\text { No }\end{array}$} & \multicolumn{9}{|c|}{ Grain diameters (mm) } \\
\hline & $>1$ & $1-0.5$ & $0.5-0.25$ & $0.25-0.1$ & $0.1-0.05$ & $0.05-0.02$ & $0.02-0.006$ & $0.006-0.002$ & $<0.002$ \\
\hline & \multicolumn{9}{|l|}{ lawns } \\
\hline 14 & 3.4 & 0.9 & 24.6 & 60.6 & 11 & 3 & 0 & 0 & 0 \\
\hline 15 & 10.8 & 1.6 & 17.5 & 55.9 & 11 & 10 & 4 & 0 & 0 \\
\hline 16 & 3.5 & 0.4 & 10.5 & 52.1 & 11 & 24 & 2 & 0 & 0 \\
\hline 17 & 3.2 & 0.6 & 25.1 & 61.3 & 11 & 2 & 0 & 0 & 0 \\
\hline 18 & 2.4 & 1.4 & 19.7 & 63.9 & 6 & 6 & 3 & 0 & 0 \\
\hline 19 & 2.7 & 0.8 & 21.0 & 53.2 & 11 & 11 & 3 & 0 & 0 \\
\hline 20 & 2.6 & 0.4 & 11.0 & 59.6 & 13 & 16 & 0 & 0 & 0 \\
\hline 21 & 5.7 & 0.6 & 18.3 & 53.1 & 12 & 12 & 4 & 0 & 0 \\
\hline 22 & 12.6 & 0.5 & 8.5 & 57.0 & 7 & 27 & 0 & 0 & 0 \\
\hline 23 & 2.9 & 1.1 & 10.7 & 38.2 & 13 & 21 & 12 & 2 & 2 \\
\hline 24 & 3.0 & 0.6 & 7.0 & 43.5 & 9 & 18 & 12 & 4 & 6 \\
\hline \multirow[t]{2}{*}{25} & 1.9 & 0.8 & 11.4 & 40.8 & 12 & 18 & 13 & 2 & 2 \\
\hline & \multicolumn{9}{|c|}{ allotment gardens } \\
\hline 26 & 1.4 & 0.7 & 12.4 & 48.0 & 15 & 17 & 7 & 0 & 0 \\
\hline 27 & 1.1 & 0.7 & 17.1 & 53.2 & 14 & 11 & 4 & 0 & 0 \\
\hline 28 & 1.4 & 0.8 & 9.1 & 49.1 & 15 & 22 & 4 & 0 & 0 \\
\hline 29 & 0.6 & 0.3 & 8.5 & 37.2 & 14 & 40 & 0 & 0 & 0 \\
\hline 30 & 3.1 & 0.6 & 13.0 & 32.4 & 13 & 22 & 10 & 8 & 1 \\
\hline 31 & 5.7 & 0.5 & 12.9 & 30.6 & 15 & 41 & 0 & 0 & 0 \\
\hline 32 & 1.7 & 0.6 & 17.5 & 52.9 & 10 & 15 & 4 & 0 & 0 \\
\hline 33 & 2.3 & 0.6 & 11.4 & 35.1 & 13 & 40 & 0 & 0 & 0 \\
\hline 34 & 3.4 & 0.9 & 11.9 & 33.2 & 17 & 18 & 12 & 7 & 0 \\
\hline 35 & 1.1 & 0.4 & 6.9 & 28.6 & 11 & 33 & 12 & 7 & 1 \\
\hline \multirow[t]{2}{*}{36} & 0.5 & 0.3 & 8.5 & 24.3 & 11 & 30 & 17 & 4 & 5 \\
\hline & \multicolumn{9}{|l|}{ fields } \\
\hline 5 & 1.4 & 0.4 & 7.3 & 32.3 & 8 & 52 & 0 & 0 & 0 \\
\hline 6 & 1.7 & 0.7 & 14.0 & 38.3 & 34 & 0 & 9 & 4 & 0 \\
\hline 7 & 7.5 & 1.5 & 14.2 & 60.3 & 9 & 11 & 4 & 0 & 0 \\
\hline 8 & 1.1 & 0.6 & 11.0 & 41.4 & 11 & 36 & 0 & 0 & 0 \\
\hline 9 & 1.6 & 0.3 & 13.9 & 49.8 & 11 & 25 & 0 & 0 & 0 \\
\hline 10 & 1.3 & 0.7 & 12.7 & 42.7 & 8 & 35 & 1 & 0 & 0 \\
\hline 11 & 1.4 & 0.7 & 10.9 & 52.4 & 7 & 17 & 8 & 4 & 0 \\
\hline 12 & 1.6 & 0.3 & 7.5 & 46.2 & 12 & 34 & 0 & 0 & 0 \\
\hline \multirow[t]{2}{*}{13} & 1.3 & 0.5 & 10.1 & 49.5 & 14 & 26 & 0 & 0 & 0 \\
\hline & \multicolumn{9}{|c|}{ fallow lands } \\
\hline 1 & 1.6 & 0.7 & 12.6 & 46.7 & 8 & 20 & 8 & 4 & 0 \\
\hline 2 & 4.2 & 0.8 & 15.1 & 40.0 & 13 & 24 & 5 & 2 & 0 \\
\hline 3 & 5.7 & 0.5 & 18.7 & 60.9 & 6 & 14 & 0 & 0 & 0 \\
\hline 4 & 3.0 & 0.7 & 21.3 & 57.0 & 7 & 6 & 6 & 2 & 0 \\
\hline
\end{tabular}

was the most favourable for the development of vegetation. A statistically significant difference was determined in the texture between allotment gardens dominated by loams, and lawns which were mainly sandy. Apart from the texture, also hydrolytic acidity and $\mathrm{C} / \mathrm{N}$ ratio differed largely in soils under both of the types of land use. In allotment gardens, the mean hydrolytic acidity was the lowest among the studied soils in Pruszków ( $p=0.17$ ). It was the highest in the soils of lawns. In spite of the evident differences in the texture of the studied soils, its effect on particular chemical properties, or even sorption capacity and organic carbon content, was not determined. Sorption capacity particularly correlated with organic carbon content $(\mathrm{p}=0.0001)$ which could occur not only in the finest fraction, as usual, but was also bound to larger particles as silt. The highest sorption capacity, considerably different from the value in the remaining soils $(p=0.0000)$ was recorded in the soils of allotment gardens (Table 2). In soils under such land use, the mean value of CEC amounted to $32.1 \mathrm{cmol} \cdot \mathrm{kg}^{-1}$. These soils also contained the highest amounts of organic carbon (mean $-21.7 \mathrm{~g} \cdot \mathrm{kg}^{-1}$ ). Observation of the carbon and nitrogen content, sorption capacity and $\mathrm{pH}_{\mathrm{KCl}}$ value reveals a certain pattern in the objects studied. Both the soils of allotment gardens and lawns are distinguished by the highest mean values of the data.

Organic carbon content clearly differentiates the soils analysed into two subgroups. One of them includes the soils of the urban zone I, i.e. those located 
in the town's centre and more exposed to anthropogenic factors. The second group includes the soils of fallow lands and fields, statistically different from the first group $(p=0.0075)$. Similar tendencies were determined by other studies. Edmondson et al. (2012) compared properties of urban and agricultural soils. They determined that urban soils contain higher amounts of organic carbon.

As a result of comparison of the surface layer of soils (up to $10 \mathrm{~cm}$ ) in urban and natural areas under similar land use, Pouyat et al. (2006) found urban soils to contain more organic carbon. In study on soils of the largest cities in Poland, Kusińska (1991) observed the enrichment of lawn soils near express roads in organic carbon. Humic acids were distinguished by high contribution of aromatic parts, and a high $\mathrm{C} / \mathrm{N}$ ratio was recorded. It is believed that organic carbon in cities can partly come from burning coal and other fossil fuels. Substances such as soot, charcoal, and other partially charred parts of plants contain elementary carbon - sometimes called black carbon (Haumaier and Zech 1995; Lorenz et al.2006; Quënëa et al, 2006; Roth et al. 2012; Yang et al. 2010). It is very stable, and has high sorption capacity.

In Pruszków, the accumulation of carbon in the soils of zone I is likely of anthropogenic origin. Soils of lawns are the most exposed to it. In those soils, the $\mathrm{C} / \mathrm{N}$ ratio is the highest, and amounts to 26.1 on the average (Table 1). Soils of allotment gardens also show carbon accumulation, but in this case it can be concluded that the carbon comes particularly from transformations of dead parts of plants, or composts and other natural organic additions. We can observe the highest accumulation of nitrogen in comparison to that of other soils (Table 2), and particularly the lowest $\mathrm{C} / \mathrm{N}$ ratio in soils under such land use. The accumulation of elementary carbon cannot be excluded of course. According to Bielińska et al. (2009), soils of urban allotment gardens are subject to dust fall. It affects not only the accumulation of carbon, therefore increasing the $\mathrm{C} / \mathrm{N}$ ratio (resulting in disturbances in the biological functioning of the soil), but also results in the alkalisation the soil. Strong alkalisation of soils is influenced by soot fall (Moretto et al. 2005; Rockne et al. 2000). It has a porous structure, correlating with high micro area and sorption capacity. No significant alkalisation was determined in the soils from Pruszków, but the values of $\mathrm{pH}$ in $\mathrm{KCl}$ are quite high as for this type of soils with such texture.

Fall of various compounds transported with dust is usually recorded in the vicinity of the source of emission (Rumpel et al, 1998). Dust analysed at various sites in Poland, however, even those with a sli- ght degree of anthropopressure and located at a large distance from cities, showed high contribution of elementary carbon (Klejnowski et al. 2010). In the studied soils from Pruszków, the determined total organic carbon amounts are not extremely high, but a very high $\mathrm{C} / \mathrm{N}$ ratio suggests disturbed biological activity, usually determined by the contents of $\mathrm{C}$ and $\mathrm{N}$ (Lorenz and Kandeler 2005). In agricultural soils of Poland the mean soil organic carbon content amounts to $13.0 \mathrm{~g} \cdot \mathrm{kg}^{-1}$ (Gonet 2007).

In spite of various disturbances in the physical and chemical parameters, certain studies showed that urban soils are metabolically active (Beyer et al. 1995; Lorenz and Kandeler 2005). Parts of cities under various land use have differing microbiological activity and related stability. The worst condition is observed in soils located near roads (Wang et al. 2011).

The present study confirms that urban soils have the potential to sequester considerable amounts of carbon. Proper management of urban soils is very important. Knowledge on their properties will permit their accurate and rational management and development planning. Another issue is classification of different used urban soils (Meuser 2010; Prokof'eva et al. 2013).

Particular attention should be paid to the soils of lawns, especially in the city center and close to transport routes, where the high accumulation of carbon was found. Addition of nitrogen compounds could improve their functioning.

\section{CONCLUSIONS}

1. The way of soil use in Pruszków town affects some properties such as content of carbon and nitrogen, $\mathrm{C} / \mathrm{N}$ ratio, sorption capacity, and exchange and hydrolytic acidity.

2. Highly statistically significant accumulation of organic carbon was recorded in the soils of zone I (lawns and allotment gardens), i.e. town centre, in relation to the soils of zone II (fields and fallow lands).

3. Although the amounts of $\mathrm{C}$ are not extremely high, the high $\mathrm{C} / \mathrm{N}$ ratio and high sorption capacity not depending on the texture, but only on carbon content, suggests the anthropogenic origin of the carbon.

4. Particular attention should be paid to the soils of lawns, especially in the city center and close to transport routes, where the highest accumulation of carbon was found.

5. The study confirms that urban soils have the potential to sequester considerable amounts of carbon. The proper management, inter alia addition of nitrogen compounds could improve their functioning. 


\section{ACKNOWLEDGMENTS}

We gratefully acknowledge the opportunity for collecting soil samples at sites in Pruszków, in particular we thank the authorities of City Hall and members of the allotment gardens.

\section{REFERENCES}

Beyer L., Blume H.P., Elsner D.C., Willnow A., 1995. Soil organic matter composition and microbial activity in urban soil. Science of Total Environment, 168: 267-278.

Bielińska E.J., Futa B., Ligeza S., 2009. Relationship between organic carbon content and the activity of selected enzymes in urban soils. Roczniki Gleboznawcze - Soil Science Annual, 60(3): 12-17.

Brown S., Miltner E., Cogger C., 2012. Carbon sequestration potential in urban soils. Carbon Sequestration in Urban Ecosystems: $173-196$.

Chuai X.W., Huang X.J., Wang W.J., Zhang M., Lai L., Liao Q.L., 2012. Spatial variability of soil organic carbon and related factors in Jiangsu Province, China. Pedosphere, 22(3): 404-414.

Edmondson J.L., Davies Z.G., McHugh N., Gaston K.J., Leake J.R., 2012. Organic carbon hidden in urban ecosystems. Scientific Reports, 2: 963, doi:10.1038/srep00963.

Gonet S.S., 2007. Protection of soil organic matter. [In:] The role of organic matter in the environment (Gonet S.S., Markiewicz M., Editors ). PTSH, Wrocław, pp. 7-29 (in Polish).

GUS, 2011. Road transport in Poland in the years 2005-2009. Information and statistical studies. Warszawa/Szczecin: 174-184.

Haumaier L., Zech W., 1995. Black carbon-possible source of highly aromatic components of soil humic acids. Organic Geochemistry, 23(3): 191-196.

Klejnowski K., Rogula P., Błaszczyk J., Rogula-Kozlowska W., 2010. Identification of organic and elemental carbon concentration in some area in Poland. Pol-Emis: 183-194. http://www.pzits.not.pl/docs/ksiazki/pol_2010.html. (in Polish)

Komisja V Genezy, Klasyfikacji i Kartografii Gleb PTG, 1989. Systematyka Gleb Polski, wyd. 4, Roczniki Gleboznawcze Soil Science Annual, 40,(3/4): 132-133. (in Polish).

Kusińska A., 1991. Transformation of organic matter in soils of greens and parks of the Lódź city. Roczniki Gleboznawcze Soil Science Annual, 42,(1/2): 101-107.

Liu Y., Wang Ch., Yue W., Hu Y., 2013. Storage and density of soil organic carbon in urban topsoil of hilly cities: A case study of Chongqing Municipality of China. Chinese Geographical Science, 23(1): 26-34.

Lorenz K., Kandeler E., 2005. Biochemical characterization of urban soil profiles from Stuttgart, Germany. Soil Biology and Biochemistry, 37: 1373-1385.

Lorenz K., Preston C.M., Kandeler E., 2006. Soil organic matter in urban soils: Estimation of elemental carbon by thermal oxidation and characterization of organic matter by solid-state ${ }^{13} \mathrm{C}$ nuclear magnetic resonance (NMR) spectroscopy. Geoderma, 130: 312-323.
Meuser H., 2010. Assessment of urban soils. [In:] Contaminated urban soils. Environmental Pollution, 18: 243-246.

Ministry of Regional Development, 2010. The development of cities in Poland - introductory report of the Ministry of Regional Development, developed for the preparation of the OECD review of national urban policy in Poland. Warszawa, pp. 30-209 (in Polish).

Moretto L.M., Silvestri S., Ugo P., Zorzi G., Abbondazi F., Baiocchi C., Iacondini A., 2005. Polycyclic aromatic hydrocarbons degradation by composting in a soot-contaminated alkaline soil. Journal of Hazardous Materials, B, 126: 141-148.

Norra S., Stüben D., 2003. Urban soils [In:] Global soils: Germany. Journal of Soils and Sediments, 3(4): 230-233.

Pouyat R., Groffman O., Yesilonis I., Hernandez L., 2002. Soil carbon pools and fluxes in urban ecosystems. Environmental Pollution, 116: 107-118.

Pouyat R.V., Yesilonis I.D., Nowak D.J., 2006. Carbon storage by urban soils in the United States. Journal of Environmental Quality, 35: 1566-1575.

Prokof'eva., Gerasimowa M., Lebedeva I., Martynenko I., 2013. An attempt of integrating the systematic of urban soils into the new Russian soil classification system. Soil Science Annual, 64(1): 24-29.

Quënëa K., Derenne S., Rumpel C., Rouzaud J.N., Gustafsson O., Carcaillet C., Mariotti A., Largeau C., 2006. Black carbon yields and types in forest and cultivated sandy soils (Landes de Gascogne, France) as determined with different methods: Influence of change in land use. Organic Geochemistry, 37: 1185-1189.

Rockne K.J., Taghon G.L., Kosson D.S., 2000. Pore structure of soot deposits from several combustion sources. Chemosphere, 41: 1125-1135.

Roth P.J., Lehndorff E., Brodowski S., Bornemann L., SanchezGarcia L., Gustafsson Ö., Amelung W., 2012. Differentiation of charcoal, soot and diagenetic carbon in soil: Method comparison and perspectives. Organic Geochemistry, 46: 66-75.

Rumpel C., Knicker H., Kőgel-Knabner I., Hűttl R.F., 1998. Airborne contamination of immature soil (Lusatian Mining District) by lignite - derived materials: its detection and contribution to the soil organic matter budget. Water, Air and Soil Pollution, 105: 481-492.

Van Reeuwijk L.P., 2002. Procedures for soil analysis (6th ed.). Tech. Pap. 9, ISRIC, Wageningen.

Vegter J., 2007. Urban soils - an emerging problem? [In:] Urban soils - An emerging problem? Journal of Soils and Sediments, 7(2): 63 .

Wang M., Markert B., Shen W., Chen W., Peng Ch., Ouyang Z., 2011. Microbial biomass carbon and enzyme activities of urban soils in Beijing. Environmental Science and Pollution Research, 18: 958-967.

Yang Y., Mahler B.J., Van Metre P.C., Ligouis B., Werth C.J., 2010. Potential contributions of asphalt and coal tar to black carbon quantification in urban dust, soils, and sediments. Geochimica et Cosmochimica Acta, 74: 6830-6840.

Received: December 18, 2013

Accepted April 1, 2014 


\title{
Wpływ urbanizacji na właściwości gleby i akumulację węgla organicznego w powierzchniowej warstwie gleb Pruszkowa - średniej wielkości miasta aglomeracji warszawskiej
}

\begin{abstract}
Streszczenie: Celem pracy było określenie właściwości gleb różnie użytkowanych i ocena wpływu antropopresji na akumulację węgla oraz azotu w glebach Pruszkowa - średniej wielkości miasta w centralnej Polsce. Przedmiotem analizy były powierzchniowe warstwy gleby $(0-20 \mathrm{~cm})$ zebrane w 36 miejscach. We wszystkich przypadkach pobierano próbki mieszane. Łącznie analizowano 12 próbek z trawników, 11 z ogródków działkowych, 9 z pól i 4 z nieużytków. Trawniki i ogrody działkowe były traktowane jako centralna strefa I - pod silną presją czynników antropogenicznych, natomiast pola i nieużytki były traktowane jako strefa II o potencjalnie niskim poziomie antropogenicznego wpływu. Analiza statystyczna wykazała istotnie wyższe $(p=0,008)$ ilości węgla organicznego (Corg) w glebach trawników (średnia $20,5 \mathrm{~g} \cdot \mathrm{kg}^{-1}$ ) i ogródków działkowych $\left(21,7 \mathrm{~g} \cdot \mathrm{kg}^{-1}\right.$ ) ze strefy I, niż w glebach nieużytków $\left(10,4 \mathrm{~g} \cdot \mathrm{kg}^{-1}\right)$ i pól $\left(1,27 \mathrm{~g} \cdot \mathrm{kg}^{-1}\right)$ ze strefy II. Powierzchniowa warstwa gleby z ogródków działkowych zawierała również znacznie większą ilość azotu ogólnego (Nt) (średnio $1,1 \mathrm{~g} \cdot \mathrm{kg}^{-1}$ ) niż gleby innych sposobów użytkowania. Nie stwierdzono zależności ilości Corg od składu granulometrycznego gleby, co w połączeniu z bardzo wysokim stosunkiem C/N sugerować może antropogeniczne pochodzenie węgla. Stosunek C/N najwyższy był w glebach trawników (wartość średnia 26,2 ) i znaczaco różnił się $(p=0,04)$ od wskaźników $\mathrm{C} / \mathrm{N}$ w glebach pól i ogródków działkowych. To wskazuje na niską intensywność transformacji humusu. Inne właściwości chemiczne, jak: kwasowość hydrolityczna, pojemność sorpcyjna, wymienne kationy zasadowe były również wyższe w centralnej części miasta Pruszkowa. Dane te wykazują wpływ urbanizacji na właściwości gleby.
\end{abstract}

Stowa kluczowe: gleby miejskie, sposób użytkowania, akumulacja węgla, azot, właściwości gleby 